\title{
An Investigation of Socially Sustainable Behaviour of Local Players in the Supply Chain of Shea Butter in Rural Borgu Nigeria: From a Role Theory Perspective
}

\author{
Sidikat Shitu ${ }^{* 1}$, Oluwatoyin Muse Johnson Popoola ${ }^{2}$ \\ ${ }^{1}$ Faculty of Economics and Business, Universiti Malaysia Sarawak, Malaysia \\ 2 Tunku Puteri Intan Safinaz School of Accountancy, Universiti Utara Malaysia, Malaysia
}

\begin{abstract}
The Shea butter industry in Nigeria is fragmented, private-driven and less regulated. This paper explores the roles, practices, and behaviour of local supply chain stakeholders who mainly consist of rural women entrepreneurs that engage in Shea nut picking and Shea butter processing. Also, the research examines the local buying agents (LBA) who serve as the middlemen between the rural women and the exporters of Shea butter. This study deploys qualitative research design, guided by the Role theory. The study reveals that the rural women and the local buying agents are the key stakeholders who participate in the agricultural supply chain. Granting the fundamental principle of the sustainable supply chain, the findings indicate that the present active engagement and practices of these local stakeholders do not align with the principles of the sustainable supply chain. The study also exposes that factors such as gender disparity, weak access to financial support, and information asymmetry are major contributors to the present roles, practices, and behaviour of the local actors. The current study, therefore, put forward several recommendations to the Nigerian Government to encourage the construction of sustainable engagement and sustainable supply chain in the rural supply chain network.
\end{abstract}

Keywords: Shea butter industry, rural women, local buying agents, supply chains, sustainable supply chain, sustainable supply chain network.

JEL Classification: F23, M11, M14, M16, M19, Q1

Paper Type: Research

\section{INTRODUCTION}

Shea butter is a natural oil or fat, which is extracted from the dried kernel of the Shea nuts derived from the fruit of the Shea trees (Lovett, 2004; Bup et al., 2012; Pouliot \& Elias, 2013; Sidibe et al., 2014). Botanically, the African Shea tree is otherwise known as Vitellaria Paradoxa formerly called Butyrospermum Parkii, sometimes referred to as

*Corresponding author: E-mail: siddyshitu@yahoo.com 
the African "women's gold," which belongs to the family of Sapotaceae (Ademola et al., 2012). Geographically, the Shea trees abound in about 21 countries in Africa south of Savannah (Lovett, 2004; Hatskevich et al., 2011; Bup et al., 2014; Global Shea Alliance 2014). Its natural habitat stretches from West Africa through Central Africa and to some parts of the East African region. It stretches from Senegal through the Central Africa Republic to Uganda (Lovett, 2004). In Africa, so many tribes have different vernacular names for Shea nut, Shea kernel, and Shea butter, but generally, the Francophone Africa countries refer to Shea nuts as 'Karite', while in the Anglophone Africa countries it is called 'Shea nuts' (Teklehaimanot, 2004). In Nigeria, the Shea trees are found predominantly in the Guinea and Sahel savannah, it is originated in the following states: Niger, Sokoto, Kebbi, Plateau, Benue, Kaduna, Oyo, Ondo, Katsina, Adamawa, Taraba, Borno, Nassarawa, Kwara and Kogi states (Kontagora, 2012). In Borgu, among the Bussa people, the Shea tree is called Kuuli, Shea nut is known as Kuuwe, Shea Kernel is called Kuu, and Shea butter is referred to as Shii Nishi or Nishi Mina.

The environment, people and culture of the local communities become the hub where Shea trees grow naturally (Naughton et al., 2015), where Shea nuts are picked, processed into Shea kernel and then to Shea butter and then traded for export and domestic uses (Fellows et al., 2014; Adesiji et al., 2015; Garba et al., 2015). In the last two decades, there have been increasing demand for organic, raw and unrefined Shea butter both domestically and internationally (Walter, 2008; Ampem \& Fadamulla 2014; Bup et al., 2014). This is as a result of the scientific discovery that stearic and oleic acid found in Shea butter can be used as coco butter equivalent (CBE) in confectionery companies (Bootello et al., 2012; Naughton et al., 2015) as well as the high demand for Shea butter in cosmetics companies, pharmaceutical companies as well as for domestic consumption especially among rural dwellers (Onikoyi et al., 2014; Garba et al., 2015; Bello-bravo et al., 2015). The continuous increase in the demand for Shea butter across the globe is attracting more and more actors with different ideology and economic enthusiasm to participate in the Shea kernel and butter supply chain and consequently causing unethical practices (Garba et al., 2015).

Local stakeholders sometimes referred to as grassroots stakeholders, are the most important stakeholders in the Shea butter industry. They reside in the rural communities where Shea butter is being processed, and these rural communities serve as the focal points for Shea butter supply chain (Lovett, 2010; Bello-Bravo et al., 2015). According to Peter Lovett (2004), Shea butter supply chain in rural areas of Africa is often informal and largely unorganised, and that is one of the major constraints in the Africa Shea industry as it is characterised by multiple markets and weak linkages. From our observation while on the field, it was discovered that in the rural Borgu, the Shea butter processing, and packaging are carried out by the rural women, and traded within the villages and townshiptraditional markets. The markets are usually unorganized, with many stakeholders engaging in unethical social, economical and environmental related practices. We saw that the largest proportion of quality Shea kernel and butter go into export supply chain while the small quantity remaining, and poor quality are sold and consumed domestically.

The sustainable supply chain has gained momentum in the academic discourse in the last two decades due to the increase in awareness on the need for corporate organizations to source for production materials ethically. The majority of the researchers exploring sustainable supply chain have their views targeted at the roles of multinational cooperate organizations in doing socially or environmentally sustainable supply chain. Researchers (Bergman et al., 2015; Carroll \& Buchholtz, 2015) have suggested that corporate social responsibility is a crucial concept. However, it is important to define sustainable supply chain. The International Chamber of Commerce, ICC guidance on supply chain responsibility (ICC 2007: p2) Opined that: "Supply chain responsibility, also referred to as 
sustainable sourcing, can be broadly defined as a voluntary commitment by companies to manage their relationships with suppliers in a sustainable way. As a result of their purchasing activities, companies may have some opportunities to influence their suppliers' social and environmental performance constructively. This can be done using several incentives such as information and training, as well as audits of suppliers' practices. According to Cooper, Lambert, and Pagh (1997) study, "whatever mechanism is used, the most efficient way to achieve sustained improvement over time is through the development of a long-term collaborative relation between corporate buyers and their suppliers, through which suppliers can internalize change by participating in the shaping of social and environmental performance objectives, based on their perception of their business capacity and needs."

\section{PROBLEM STATEMENT}

Shea kernel and butter are sourced from rural Borgu in an unethical manner by external players who remain invisible in the focal point of supply, but use the local buying agents to purchase the products on their behalf, and hence, taking advantage of the unregulated nature of the Shea butter industry in Niger state, Nigeria. The National Bureau of Statistics in February 2012 reported that 112.519 million Nigerians live in relative poverty conditions, where it is estimated that Niger state, has 43.6 percent (Omoyibo, 2013). Poverty is perceived to be the driving force behind the engagement of the rural stakeholders in unethical practices in the Shea butter industry. Desperation for family needs, force suppliers to sell their kernel and butter at a cheap and give away prices. Consequently, the local buying agents take advantage of the women's desperate need and poverty situation to buy their products at extremely low prices and further sell at exorbitant prices at the larger domestic and international market. However, the meager prices being paid for Shea kernel and butter force the local community members to engage in unsustainable practices such as cutting down of Shea trees for firewood and charcoal as an additional source of income to meet up with their pressing basic needs. Therefore, this study would limit its scope to the socially sustainable practices of local stakeholders involved Shea butter supply chain in the rural communities of Borgu, Niger state, Nigeria.

\section{RESEARCH OBJECTIVES}

Evidently, the increase in participation of local actors in the Shea butter industry has not brought about any meaningful change in the socioeconomic condition of rural Borgu communities. Therefore, this paper seeks to examine the current practices, roles and behaviour of local stakeholders involved in Shea butter supply chain in the context of the socially sustainable supply chain.

\section{RESEARCH QUESTION}

How do the roles, practices, and behaviour of local stakeholders in the Shea butter industry shape socially sustainable supply chain in rural Borgu?

\section{THEORETICAL FRAMEWORK}

We utilized the Role theory as the foundation of our study. Role theory happens to be a suitable conceptual research framework to elucidate and comprehend relationship, roles and practices of actors in this context. Understanding the roles that the key players play especially at the grassroots is paramount for the management of a socially sustainable 
supply chain. In the Shea butter industry, local stakeholders have different interests. Therefore, to achieve a sustainable supply chain, local stakeholders must be involved in the process going from the ethical point of view of the Role theory that accords more priority to communication and relationships (Hocutt \& Stone, 1998). Role theory describes how people act or behave in their day-to-day activities and how individuals respond to societal expectations. In a broader term, role theory focuses on people's behaviour. From the research questions, it is evident that the thought about actors' role in supply chain network is concerned in more specific behavioural social context. Since a significant number of studies from sociology, psychology, management, education and nursing have used role theory to analyse the approach people are to play such that a stable society can be maintained.

Role theory addresses how people act in response to social expectations and the expectations that shape roles are often between individuals or group (Floyd \& Lane, 2000). It explains the interaction between people in a group or an organization focusing on the roles they play (Thompson \& Greene, 1994). Concisely, it is shaped by expectations (Turner, 2001). It is useful in the interpretation of personalities from both social and psychological angles (Shivers-Blackwell, 2004). The concept of role is usually understood in many ways. However, the main focus of the Role Theory is on individual behaviour where "role" is defined as a chain of expected behaviour models which is prescribed by a person's social status and personal characteristics such as gender and age (Bengtsson \& Kock, 2015). Individuals have to play "appropriate" roles according to social expectations (Turner, 2001). However, changes in culture may challenge the traditional social roles of individuals and dictate new ones. Through role-playing, individuals are in a better position to perceive traditional as well as new social expectations to get a clear understanding of their self-image. In a nutshell, a role can be viewed as the pattern of expectations, which is often about behaviour that applies to a particular social position (Koenig \& Eagly, 2014) such as father, teacher, apprentice, among others.

\section{METHODOLOGY}

This paper research type is qualitative, and the research design is a case study. The conduct of the study is fieldwork research method in Rural Borgu, Borgu Local Government Area of Niger State, Nigeria from December 2014 to April 2015. The rural Borgu is a boundary zone that represents one of the major production areas of Shea kernel and butter. Most importantly, it symbolizes a gateway for smuggling of Shea products out of Nigeria in an unethical way into the neighbouring country of Benin Republic Nigeria. This study adopted the exploratory approach to getting an in-depth picture of the domestic supply chain of Shea kernel and butter. Emphasis on studying the actors in their natural setting is considered paramount. The data collection techniques adopted for the study comprise semi-structured interview, participants' observation, focused group discussions and story-telling.

\subsection{Case Study Area}

Tsohon-Dogongari and Karabonde are villages under Rafi district of Borgu local government in Niger State, Nigeria. Tsohon-Dogongari is about 5-kilometre drive to the Emir of Borgu's Palace in New Dogongari, its location is considered to be most strategic for buyers of kernel and butter who must enter Borgu through New-Bussa while Karabonde is about 6-kilometre drive to the Emirate Council and Old Palace. In the two case villages, women and children (girls) are the major participating actors in the Shea butter industry. Our decision to select these two villages was based on three major factors. First, the 
location of the area supports international trade. Second, Borgu is a smuggling route for Shea products to the Benin Republic and other West African countries. Third, the history, Borgu is known for trade and quality Shea production since the pre-colonial era. Furthermore, field observation revealed that people from different parts of Nigeria reside in Borgu and within the case Villages different languages were heard spoken by the people apart from Bussa language.

\subsection{Overview of Borgu Domestic to Export Supply Chain}

In Borgu, the domestic supply chain of Shea kernel and butter consists of numerous actors within the rural communities. The product has to pass through different actors who relate with one another to ensure the product gets to where it is needed. The actors are the local community members who consist of the Shea nut pickers, Shea butter processors (suppliers) and the local buying agents. In Borgu, the Shea peak season begins in June and ends in August because the area is located in the Guinea savannah belt of Nigeria (Anadu \& Green, 1990). Shea kernel is traded all year round in the major commercial quantities for the months of September and November. Many women and children regardless of ethnic group or tribe participate in the collection of Shea nuts during the peak season, but not everyone is involved in Shea butter processing. Most prominent among these tribes are the Bussawa, Laro, Lupawa, Yalawa, and Nupe.

Some of the buyers source their products directly from the focal point of supply in the villages where Shea is processed, they repackage the goods and send to the larger domestic and international markets. The major constraint to suppliers in Shea kernel and butter supply chain is that the local buying agents often take advantage of the grassroots women's lack of education, poverty and information asymmetry and exploit the suppliers by buying Shea products at very low prices in the villages. To reduce the rate of exploitation and uncertainty, the suppliers take their products to the major township, traditional markets in New-Bussa, Guvanti, Babbana, and Sabon Pegi. In these markets, there are many small traders who participate in the Shea business. The markets are usually open on a weekly basis, or every fourth night, traders from different villages transport their products by road using trucks and converge in these markets to sell their products through bargaining interactions.

The grassroots actors enjoy the liberty of doing Shea business, the government do not interfere at the collection or selling point of Shea products, not even the Local Government Authority because of their closeness to the grassroots are able to control Shea supply chain even though the federal government officials in the custom and immigration service are stationed in Babbana area of Borgu local to monitor the activities of smugglers along the Nigeria- Benin Republic border due to the high rate of smuggling of Shea kernel from Nigeria to Parakou in the Benin Republic. Although the local stakeholders have agitated for external support towards ensuring a socially and environmentally sustainable supply chain is achieved in the Shea butter industry. Having understood that the success of the collective actions of all the stakeholders greatly depends on the level of participation and responses from actors at the focal point of supply which is the rural communities and the relationship that exist between the suppliers and the buyers. For the purpose of this paper, the roles and practices of suppliers and the local buying agents in the supply chain of Shea kernel and butter shall be the major focus of discourse in the context of the sustainable supply chain.

The domestic and export supply chain of Shea kernel and butter from the focal point of supply to the final consumers is demonstrated in Figure 1. It shows the movement of Shea products from one point to the other. The actors involved are the local community, Shea nut pickers, Shea butter processors, local buying agents, small traders, small 
companies, exporters and the consumer. Also, in this Figure 1, the forest where the Shea trees grow is captured as a stakeholder.

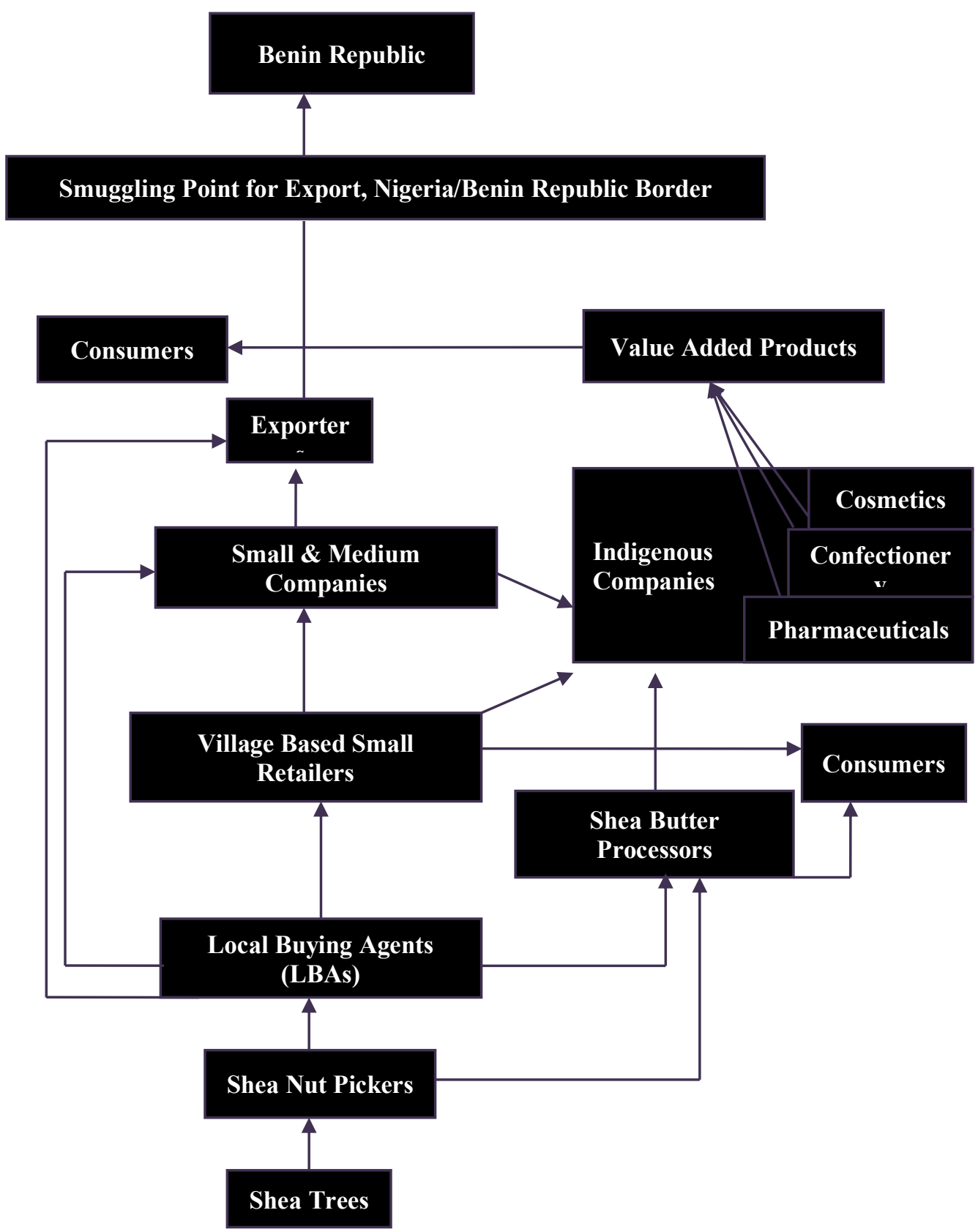

Figure 1. Borgu Shea Kernel and Butter Domestic Supply Chains Source: Fieldwork experience January to April 2015

\section{FINDINGS AND DISCUSSIONS}

In Borgu, roles are determined by gender in the Shea butter industry. The local buying agents are men while the Shea nut pickers and butter processors are predominantly women. The traditional method of processing is the only method of processing used by the rural women. 


\subsection{Shea Nut Picking and Kernel Processing}

The practice of Shea nut collection is seasonal in Nigeria, the peak season for Shea nut collection is between the months of June and August. The Shea nut pickers or collectors are regarded as the most important actors in the supply chain, and they are predominantly poor women of reproductive age, children, and the senior women. During the peak season, the majority of the kids do not go to school on a regular basis especially the girl-children who help their mothers in Shea nuts collection. This is against the Nigerian child rights 2003 (CRA), Section 30, No 2b, which states "A child shall not be used for any purpose that deprives the child of the opportunity to attend and remain in school as provided for under the compulsory, Free Universal Basic Education Act." Realistically, though, there is a mixed perspective to whether children should participate in Shea nut picking during school days or hours, this is confirmed by the response of one of the interviewees.

"Sometimes Shea nut picking affects our children because most times we pile up heaps of Shea nuts in the farm and we ask the children to bring them back home before going to school in the morning sometimes they get late to school and some days they don't even go to school during the peak season, if they don't participate, there will be no enough money to feed them, even though I am not too happy by involving my children."

They Shea nut pickers leave their homes very early in the mornings during the peak season and trek long distance in the bushes where they locate Shea trees and collect Shea nuts. Usually, Shea nut picking outside family farmlands is a matter of competition and rivalry because the trees grow in the wild and are considered as a community or common property owned by all. On most occasions, the women leave their homes as early as 5.30 a.m. in search of fallen ripped nuts, this is done on a daily routine basis. The women spend at least 7 to 10 hours walking distance moving in the group from one Shea tree to the other and in the process, they are mostly exposed to dangers of being attacked by reptiles such as snakes, and other dangerous animals.

Also, nuts are picked on family farmlands where Shea trees are naturally distributed. The women pick the nuts in the bushes before the ones on their family farmlands this is because families claim ownership to the trees on their farmlands and it is considered as a family property. The Shea trees and nuts on farmlands are safe from theft because in Borgu it is a taboo to pick Shea nuts on other people's farmlands without permission. Shea nut picking is hectic and very undesirable since the trees are not yet domesticated. The Shea nut pickers interviewed expressed how they feel moving around in the bush to collect Shea nuts.

"Moving from one tree to the other is a very tedious task and carrying heavy nuts on the head from the farm to my house is such a difficult thing to do."

The women make sure they process the nuts within five days to avoid nuts germination while piling up the nuts. Because Shea nuts left unprocessed for more than seven days may germinate and can lead to a reduction in quality of kernel where the level of free fatty acid (FFA) may increase to between $0.22 \%$ and $1.66 \%$ (Obibuzor, 2013). The processes involved in getting kernel out of the nuts require careful selection of nuts by picking only the matured nuts that drop naturally from the Shea trees. After collection, the usual norms or practices require the processing of the nuts in many stages by a group of women and children (that is, labour intensive). De-pulping the fleshy layer of the fruit is 
the first stage, followed by parboiling the nuts, then draining the nuts, then drying the nuts on a clean floor free from chemical and animal droppings though the process is usually disrupted by unpredicted weather condition such rainfall and sand wave which could lead to damage of the kernel as reported by Nahm (2011). This process is followed by cracking and removal of the kernel from the shell, then re-drying the kernel for 3 to 4 days, and finally packaging in jute sacks. The small jute sack weighs approximately $100 \mathrm{lbs}$, while the big jute sack weighs about $200 \mathrm{lbs}$, and then storage. In most homes, the Shea kernel is stored in the grains store.

The Shea nut pickers have several options after kernel is processed, they either use by themselves to process Shea butter or sell to other Shea butter processors within their locality at a price range of between NGN600 and NGN1000 (Nigerian Naira) per basin, depending on the season which is usually sold on credit or they hoard it against scarcity and sell to the local buying agents. Alternatively, when they have pressing needs for money, they sell to the local buying agents in the 'Monday' traditional market in New Bussa or Sabon Pegi at very low prices ranging between NGN400 and NGN600 per basin depending on the period of the year. Logistics is a major challenge to the nut pickers, the women in Karabonde village walk 6-7 hours daily to get their products sold at the Monday market in New Bussa, and the women in Dogongari village have to board a truck to the Monday market because the distance is not trek-able.

The option of the women taking their products to the traditional markets is the most rational option because they sell products and receive payment instantly, but the women are usually unsatisfied with the price of kernel and butter. One of the interviewees expressed their dismay on the prices buyers offer them, and they described it as exploitation.

"Sometimes I sell my kernel in Monday traditional market, when I have kernel in excess, I sell to the 'hausas' they offer meager prices and complain about the quality of my kernel, I am not satisfied with the behavior of the buyers because they don't appreciate the risk involved in Shea nut picking"

The women's greatest fear is that Shea trees are disappearing from the bush. This was lamented by the women during the focused group discussions in Karabonde and TsohonDogongari:

"The community protects the Shea trees by being vigilant and through forest guards assigned by the government, but even with our efforts people still cut down the Shea trees especially the ones in the wild."

The reason why people prefer to use the Shea trees for firewood and charcoal is that of the belief that Shea tree being an oil fruit producing tree is excellent for firewood and charcoal (Maranz et al., 2004).

\subsection{Shea Butter Processing and Marketing}

In processing Shea butter, three methods were used. First, the traditional method of processing that has been in existence since time immemorial. Second, semi-mechanised methods commonly employed in the Shea butter villages and small factories. Third and the last method is the mechanised method of processing (Adaquaye, 2004). From our observation on the field, women in rural communities of Borgu still use the traditional method of processing. In this paper, we consider the traditional method of processing. Borgu women, despite the infrastructural challenges, use their local initiative to come up 
with best processing practice and approaches. They wash the Shea kernel first, dry it and then sort the wrong kernel from the real kernel, followed by crushing the nuts with mortar and pestle, then roasting, milling and kneading the kernel until the butter is due to separation from waste using plenty of water. The last stage of processing requires boiling of crude Shea fat, filtering, and packaging.

Borgu women produce Shea butter individually usually in small scale for domestic consumption, domestic factory owners, and export. From the responses of the Shea butter processors, there is an indication that changes had occurred in the traditional method of processing over a period.

"What has changed is that in those days we process Shea butter in the bush and also grind Shea kernel on stones, but now we process Shea butter in our homes, and also we use grinding machines. Though the machine is not specially fabricated to grind Shea kernel, the machine is supposed to be used to grind grains, but we use it as an alternative means of grinding Shea kernel."

Women in Karabonde, Tsohon-Dogongari and other villages in Borgu where Shea butter is processed had formed village cooperative groups; each village has a registered Shea cooperative society under the Social Development Department of the Borgu Local Government Authority sequel to the intervention from the state and non-state actors in the Shea butter industry. Notably among the interventions are the FADAMA, a World Bank/Federal and State Government Assisted Project, German Agency for International Development (GIZ), Niger State Commodities and Export Promotion Agency (NSCEPA), Borgu Local Government Authority and the Nigerian Export Promotion Council (NEPC). The Cooperative Societies are created to develop an enabling environment for suppliers and buyers to do sustainable business, have access to information and market opportunities as well as access to loans from microfinance institutions. Despite the intervention, the Cooperative groups have not received equal training opportunities. For instance, Dogongari cooperative group benefitted from the intervention better than the Karabonde group.

This is evident in the responses of the women interviewed. In Karabonde the respondents stressed that

"Nobody has come to train us on anything about Shea butter processing but the government officials always come to ask us questions just like you are doing now and sometimes the government will promise to help us but nothing has been done to assist us. Government officials have never trained us before, but they had come severally to see our traditional methods of processing."

While in Tsohon-Dogongari village, the women attested to the fact that they had enjoyed training from different levels of government and non-governmental organizations. Some of their responses are:

"I have benefited in at least three different pieces of training organize by the government the last one was organised by government officials from Abuja."

From the researcher's interactions with the women during one of the focused group discussions with the members of the cooperative groups in Karabonde and TsohonDogongari, the women made it clear that the cooperatives are not functioning properly due to the fact that the members who are all women are chiefly illiterates, they have to employ 
the services of a literate person, a male to be precise, within the community to assist in coordinating the cooperative and keeping records. The coordinators are not always available in the village because they work with local government authority in New-Bussa. Also, the buyers are not willing to buy kernel and butter through the cooperatives and as such there is no formal arrangement between the suppliers and the buyers, which mean supply is still done in a decentralized manner.

Our study revealed that the buyers of Shea butter prefer to buy from individual members of the Cooperative Society at lower prices to cut cost rather than buy through the Cooperative, which can fix and negotiate price. The members of the Cooperatives are breaking the law that binds them together as an entity by secretly selling Shea buyers without the consent of the Cooperative and the Local government authority. The members made it clear during the focus group discussion sessions in Karabonde that the buyers' do not come on regular basis, so the women see the buyers once in a while appearance as a golden opportunity for them to quickly sell their butter for any price for fear of not knowing when next the buyers would come.

Furthermore, lack of access to finance is a major setback for the Shea butter processors. Financial institutions do not give loans to unorganised group of people, and this greatly affects the production capacity of the women and subsequently hindering direct linkage to wider domestic market and as such they are conditioned to the prefinancing arrangement by the local buying agents who use exploitative measures to source for kernel and butter from the women processors.

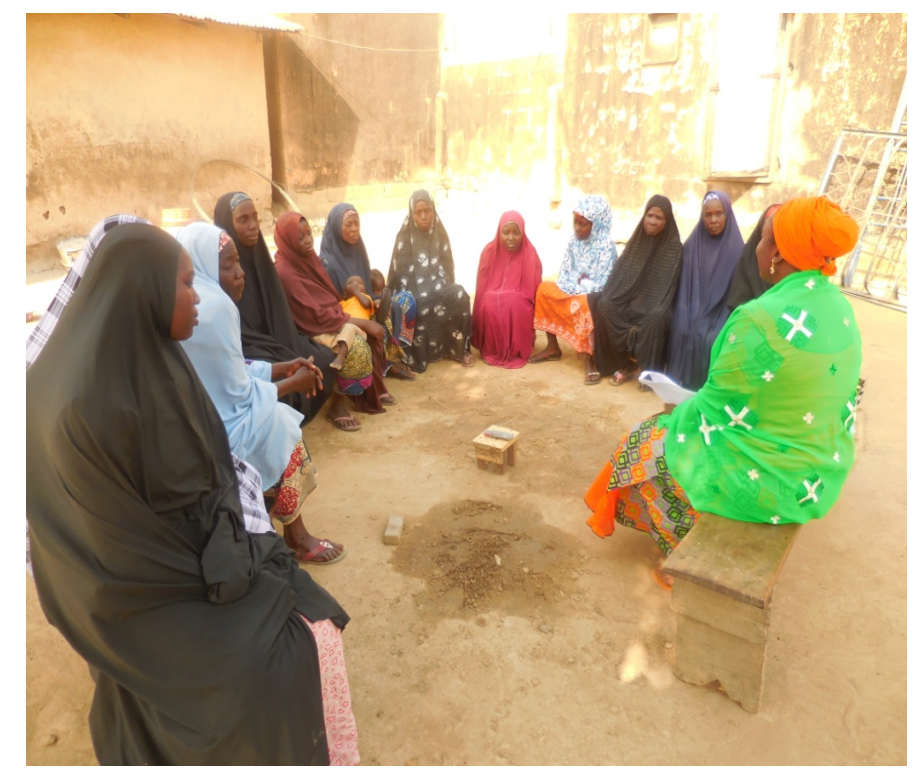

Figure 2. Focused Group Discussion in Tsohon-Dogongari Village

Source: Field work February 2015. Focused Group Discussion Session in Karabonde Village

In the two case villages, a significant number of teenage girls who are supposed to be in school are seen processing Shea butter in the processing clusters as shown in Figure 3, Most specifically, they hawk Shea butter in public places and go to the traditional markets to sell during school hours. The situation is that of child labour because the most affected girls are under 18 years of age. The incident of child labour abuse is linked to perceived potential price exploitation of the women processors by the individual buyers or agents. The resultant effect encourages the women to package Shea butter in piecemeal and hawk by girls for more profit. 


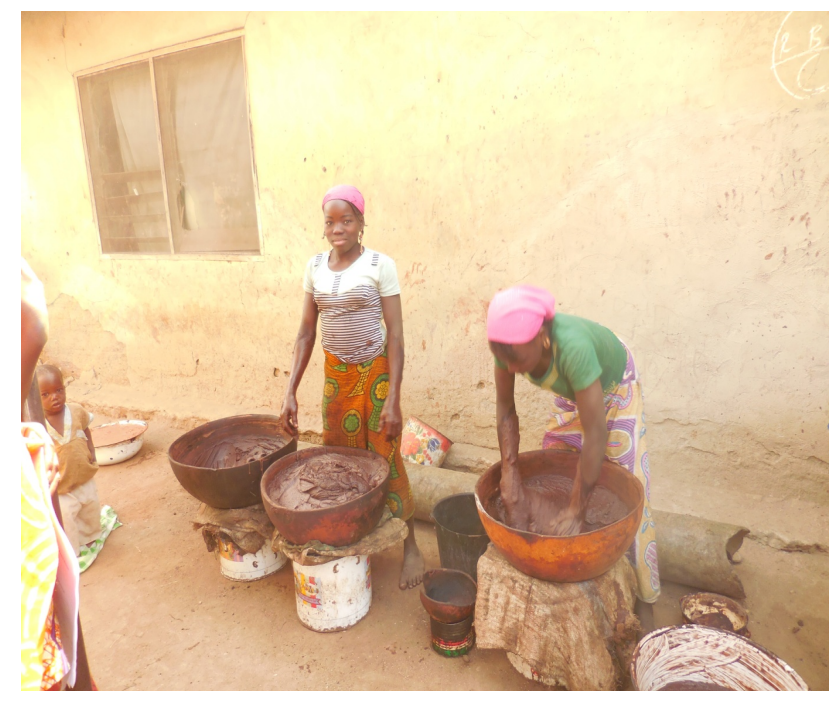

Figure 3. Young Teenage Girls Processing Shea Butter in Karabonde Village

Source: Fieldwork April 2015. Child labour in Shea butter processing, girls below age 18, kneading Shea paste

\subsection{Shea Kernel Enterprise}

The local buying agents (LBA) are found in all the localities where Shea kernel and butter is processed. The LBAs are the only group of men who participate actively in Shea trading; they are of three categories, namely: those that buy only Shea kernel, those that buy Shea butter only, and those that buy Shea kernel and butter. The LBAs act as intermediaries between the company owners, exporters, and the suppliers. They purchase Shea kernel and butter directly from Shea nut pickers and Shea butter processors in the villages on behalf of the exporters, companies, and send directly to the factories where the semimechanised method of butter extraction and value addition is done.

One of the most significant changes in the Shea industry in the last two decades, which has had an impact on the Shea butter industry has been the increased interest of small factory owners in Shea butter produced in Borgu. History has it that Borgu have the best processing method for Shea butter. In this context, the local buying agents (LBAs) are the key actors who shape the larger domestic and international supply chain. They are usually non-licensed. They reside in the rural villages around New-Bussa, the headquarters of Borgu Local Government where the traditional Monday Market is located. They have a very cordial relationship with the suppliers. Their relationship is not limited to buying Shea kernel and butter but also pre-finance the suppliers who need money urgently to solve immediate pressing needs and payback with either kernel or butter later on. A local buying agent responded to the question of whether they buy kernel on credit.

"We pay for Shea kernel instantly, there is no need to buy kernel on credit from our suppliers, the factory owners had paid us in advance, so we pre-finance the women before the Shea peak season and when the season comes they pay us back with the kernel."

The relationship that exists between the local buying agents and their principal (the company owners) is subject to the ability of the LBAs to stick to time for product delivery, ensure they purchase the best quality of Shea and the right quantities demanded. The 
local Shea buying agents who represent their principals, buy in the major commercial quantities since there is no any fixed structure put in place to check the sourcing of Shea at the grassroots. If there is a wide gap in the requirements, then continuity in transacting business between the agents and their principals becomes uncertain.

In the process of transacting business with the local supplier's price exploitation occurs, the LBAs dictate the prices of kernel and butter in the claim that as agents, they also incur loss and shortage during storage, transportation, and payment of tax. The LBAs engage in village-to-village sourcing of Shea nuts and butter during periods of scarcity or during the years with low yields of nuts as there is no guarantee of stability in the yield of Shea nuts. The prices of low-quality Shea butter are different, the irony in it is that the women who sold Shea kernel to the LBAs go back in turn to the LBAs to buy kernel for Shea butter processing during scarcity. The agents reserve the poor-quality nuts for the women and sell it back to them. While the best qualities are sent to the larger domestic market and exporters who take it to the foreign markets. One of the respondents mentioned the destination for kernel sourced in rural Borgu

"We sell to factory owners from Kano, Northern Nigeria, Ghana, Togo and the Benin Republic we also sell to rural women who process Shea butter."

As soon as the kernels are purchased, they are sorted according to grade levels, stored in big jute sacks, and kept in the warehouse to await the arrival of the company owners from the Benin Republic for immediate delivery. Sometimes the LBAs arrange for the logistics and act as the supply chain managers. They transport the products by road using long distance vehicles such as trailers and trucks across the porous border of Nigeria and Benin- Republic through Babbana to Parakou.

\section{CONCLUSION AND RECOMMENDATIONS}

The Nigerian Shea butter industry is a promising industry that has the highest potential to attract foreign investors and reduce poverty at the grassroots if properly coordinated. In the context of Borgu, the local stakeholders needs external support and the government must quickly assume leadership role in checking the unethical practices in the Shea industry by introducing viable rules and regulations that will protect the Shea trees, women and children involved in the Shea butter industry in the demoralising situation existing in the Shea butter industry such as Shea tree cutting, bush burning, price irregularities, use of child labour and exploitation

Unknown foreign companies control the Borgu Shea kernel market with the support of private individuals through the local buying agents. Poverty has made the exploitation of the rural women possible. The lack of information and direct connection to the women with the foreign and large domestic market as well as the inability of the cooperatives to access loans from the financial institutions has hindered the local stakeholders in performing sustainable supply chain.

The government should come up with policies that will look into the plight of the Shea nut pickers and Shea butter processors so that they can benefit handsomely in the supply chain within their local communities by providing market information, training on value addition, wealth creation and monitoring of supply chain activities. The study recommends the creation of Shea marketing board to check the operations of the local buying agents through the implementation of sustainable supply chain agreements between the local buying agents and the local government authority at the grassroots.

Finally, there is a need to build the capacity of Shea butter cooperative societies in the rural communities where Shea is produced. Since it is evidently clear that a lack of 
trust exists and zeal for joint marketing among the members of the Cooperative Societies; nongovernmental organizations, financial institutions, and the government can play a major role in strengthening the capacity of the cooperatives. If this is done, the local stakeholders may adopt behavioural change and work collectively towards attaining a sustainable supply chain in the Shea butter industry.

\section{REFERENCES}

Addaquay J (2004). The Shea Butter Value Chain Refining in West Africa WATH, Technical Report No 1 USAID, Washington DC. 21-25.

Ademola, A. O., Oyesola, O. B., \& Osewa, S. O. (2012). Assessment of Shea Butter Processing among Rural Dwellers in Atisbo Local Government Area of Oyo State, Nigeria. European Journal of Business and Social Sciences, 1(6), 1-8.

Adesiji, G. B., Olarewaju, K. D., Olaleye, R. S., \& Komolafe, S. E. (2015). Assessment of indigenous methods of processing shea butter among women in llorin East local government area of Kwara state, Nigeria, Journal of Agricultural Sciences, 60(2), 199-210.

Ampem, I., \& Fadamulla, P. (2014). Benefit-cost analysis of producing Shea butter. Bachelor Thesis, University for Development Studies Ghana.

Anadu, P. A., \& Green, A. A. (1990). Nigeria. Antelopes: Global Survey \& Regional Action Plans, Part, 3, 83-90.

Bello-Bravo, J., Lovett, P. N., \& Pittendrigh, B. R. (2015). The Evolution of Shea Butter's" Paradox of paradoxa" and the Potential Opportunity for Information and Communication Technology (ICT) to Improve Quality, Market Access and Women's Livelihoods across Rural Africa. Sustainability, 7(5), 5752-5772.

Bengtsson, M., \& Kock, S. (2015). Tension in Coopetition. Creating and Delivering Value in Marketing (pp. 38-42). Springer International Publishing.

Bergman, M. M., Leisinger, K. M., Bergman, Z., \& Berger, L. (2015). An Analysis of the Conceptual Landscape of Corporate Responsibility in Academia, Business and Professional Ethics Journal, 34(2), 165-193.

Bootello, M. A., Hartel, R. W., Garcés, R., Martínez-Force, E., \& Salas, J. J. (2012). Evaluation of high oleic-high stearic sunflower hard stearins for cocoa butter equivalent formulation. Food Chemistry, 134(3), 1409-1417.

Bup, D. N., Abi, C. F., Tenin, D., Kapseu, C., \& Tchiegang, C. (2012). Optimisation of the cooking process of Shea nut kernels (Vitellaria paradoxa Gaertn.) using the Doehlert experimental design. Food and Bioprocess Technology, 5(1), 108-117.

Bup, D. N., Mohagir, A. M., Kapseu, C., \& Mouloungui, Z. (2014). Production zones and systems, markets, benefits and constraints of Shea (Vitellaria paradoxa Gaertn) butter processing. OCL, 21(2), D206.

Carroll, A. B., \& Buchholtz, A. K. (2015). Corporate Citizenship: Social Responsibility, Responsiveness, and Performance. Classics of Organization Theory, 439.

Carroll, A., \& Buchholtz, A. (2014). Business and Society: Ethics, Sustainability, and Stakeholder Management. Cengage Learning.

Fellows, P. (2014). Insect products for high-value Western markets. Food Chain, 4(2), 119-128.

Floyd, S.W. and Lane, P.J. (2000). Strategizing throughout the organization: managing role conflict in strategic renewal. Academy of Management Review, 25, 154-177.

Garba, I. D., Sanni, S. A., \& Adebayo, C. O. (2015). Analyzing the Structure and Performance of Shea Butter Market in Bosso and Borgu Local Government Areas of Niger State, Nigeria. International Journal of u-and e-Service, Science, and Technology, 8(2), 321-336.

Hatskevich, A., Jeníček, V., \& Antwi Darkwah, S. (2011). Shea industry-a means of poverty reduction in Northern Ghana, Agricultura Tropica et Subtropica, 44(4), 223-228.

Hocutt, M. A., \& Stone, T. H. (1998). The impact of employee empowerment on the quality of a service recovery effort. Journal of Quality Management, 3(1), 117-132.

International Chamber of Commerce (2007). ICC guidance on supply chain responsibility 
Koenig, A. M., \& Eagly, A. H. (2014). Evidence for the social role theory of stereotype content: Observations of groups' roles shape stereotypes. Journal of Personality and Social Psychology, 107(3), 371.

Kontagora, A. (2012). Shea sector development in Nigeria, issues, challenges and way forward (pp.1-11). Retrieved from http://www.slideshare.net/watradehub/kontagora-nscepa-shea2013-wordy-draft1

Lovett, P. (2004). The shea butter value chain: Production, transformation and marketing in West Africa (Technical Report No 2), West Africa Trade Hub (WATH). USAID.

Lovett, P. N. (2010). Sourcing shea butter in 2010: A sustainability check. Global ingredients \& formulations guide, 62-68.

Maranz, S., Kpikpi, W., Wiesman, Z., De Saint Sauveur, A., \& Chapagain, B. (2004). Nutritional values and indigenous preferences for Shea fruits (Vitellaria paradoxa CF Gaertn. F.) in African agroforestry parklands. Economic Botany, 58(4), 588-600.

Nahm, H. S. (2011). Quality characteristics of West African Shea Butter (Vitellaria paradoxa) and approaches to extend shelf-life (Doctoral dissertation, Rutgers University-Graduate SchoolNew Brunswick).

Naughton, C. C., Lovett, P. N., \& Mihelcic, J. R. (2015). Land suitability modelling of shea (Vitellaria paradoxa) distribution across sub-Saharan Africa. Applied Geography, 58, 217-227.

Obibuzor, J. U., Abigor, R. D., Omoriyekemwen, V., Okogbenin, E. A., \& Okunwaye, T. (2013). Effect of processing germinated Shea kernels on the quality parameters of Shea (Vitellaria paradoxa) butter. Journal of Cereals and Oilseeds, 4(2), 26-31.

Omoyibo, K. U. (2013). Leadership, Governance, and Poverty in Nigeria. Mediterranean Journal of Social Sciences, 4(6), 29.

Onikoyi, M. P., Tijani, S. A., \& Oluwasusi, J. A. (2014). Factors associated with Shea butter processing in Kwara State, Nigeria. International Journal of Agriculture Innovations and Research, 2(5), 710-716.

Pouliot, M., \& Elias, M. (2013). To process or not to process? Factors are enabling and constraining Shea butter production and income in Burkina Faso. Geoforum, 50, 211-220.

Shivers-Blackwell, S. L. (2004). Using role theory to examine determinants of transformational and transactional leader behavior. Journal of Leadership \& Organizational Studies, 10(3), 41-50.

Sidibe, A., Vellema, S., Dembélé, F., Témé, B., Yossi, H., Traoré, M., \& Kuyper, T. W. (2014). Women, Shea, and finance: How institutional practices in a Malian cooperative create development impact. International Journal of Agricultural Sustainability, 12(3), 263-275.

Teklehaimanot, Z. (2004). Exploiting the potential of indigenous agroforestry trees: Parkia biglobosa and Vitellaria paradoxa in sub-Saharan Africa. In New Vistas in Agroforestry (pp. 207-220). Springer Netherlands.

Thompson, K. H., \& Greene, R. R. (1994). Role theory and social work practice. Human Behavior Theory: A Diversity Framework, 93-114.

Turner, R. H. (2001). Role theory. In Handbook of sociological theory (pp. 233-254). Springer US.

Walter, S. (2008). Impact of certification on the sustainable use of nwfp1: lessons-learnt from three case studies. RDE-Revista de Desenvolvimento Econômico, 5(8), 1-14. 